\title{
Pre-Plant Fumigation of Soils for Nematode Control Affects the Seedling Production and Morphological Properties of Pine and Larch Seedlings
}

\author{
Sangsub Cha ${ }^{1}{ }^{\mathbb{D}}$, Jeonghwan Kim ${ }^{1}$, In Gyu Choi ${ }^{2}$, Jongo Choi ${ }^{3}$, Hyerim Han ${ }^{4}$, Namin Koo ${ }^{1}$ \\ and Yong Suk Kim ${ }^{1, *(\mathbb{B}}$ \\ 1 Forest Conservation and Restoration Division, National Institute of Forest Science, Seoul 02455, Korea; \\ sscha81@naver.com (S.C.); biostatistics@korea.kr (J.K.); koosor@korea.kr (N.K.) \\ 2 Korean Society of Forest Environment Research, Namyangju 12014, Korea; zuaeri@naver.com \\ 3 Pyeongchang National Forest Station, Korea Forest Service, Pyeongchang 25359, Korea; giograpic@korea.kr \\ 4 Forest Insect Pests and Disease Division, National Institute of Forest Science, Seoul 02455, Korea; \\ hrhan123@korea.kr \\ * Correspondence: soilys@korea.kr; Tel.: +82-02-961-2637
}

Received: 12 August 2019; Accepted: 26 September 2019; Published: 26 September 2019

\begin{abstract}
Using a fumigation sterilizer (Dazomet) for nematode control, this study determined the effect of soil sterilization on the quantity and quality of the growth of Pinus densiflora Siebold \& Zucc. and Larix kaempferi (Lamb.) Carrière seedlings in an open-field nursery at Jeongseon-gun, Kangwon-do, Republic of Korea. Most soil nematodes disappeared after fumigant sterilization. The organic matter content, cation exchange capacity, and $\mathrm{Mg}^{2+}$ content of the soil increased significantly, but the electrical conductivity (EC) decreased. The quantity of pine and larch seedlings was highly correlated with the soil nematode density. The soil properties changed due to soil fumigation, which affected the growth of both species. Pine seedling growth was affected by the soil chemical properties, such as available phosphorus (AP), $\mathrm{Ca}^{2+}, \mathrm{Mg}^{2+}$, and $\mathrm{EC}$, and the growth of larch seedlings was affected by the EC and nematode density. The quality of the pine seedlings improved, whereas that of larch did not. This was a result of the difference in their tolerance to soil salinity. The seedling quality index (SQI) of the two species was related to the EC, but the pine seedlings were more affected by the EC, indicating that the control of soil nematodes by fumigant treatment significantly increased the quantity of seedlings produced and partly improved their quality. Soil management using a fumigant treatment was more efficient for producing pine seedlings than larch. Our results can be used to improve agricultural and forestry economics.
\end{abstract}

Keywords: soil fumigation; soil nematode density; soil chemical properties; major conifer species; seedling quality index

\section{Introduction}

Worldwide, forest ecosystems are seriously disturbed by various factors, and forest management is required in many countries. In Korea, forest management aims to control disturbances and afforestation, to offset the decline in forests. Nine million seedlings are produced annually in open-field nurseries in Korea to afforest large areas [1].

Some factors (particularly soil pests) that disrupt the forest ecosystem also affect seedling production in open-field nurseries. The survival rate of seedlings decreases as soil conditions change in an open-field nursery, and seedling growth is affected by such changes. The change in plant growth also affects seedling quality. Assessments of seedling quality can be used to predict their field performance [2], and the success of forestation is influenced by seedling performance [3]. As low-quality 
seedlings are less viable [4-6], improving the quantity and quality of seedlings by managing the nursery is an important first step.

Soil in nursery fields is managed by various methods [7-10]. Soil sterilization via fumigation is a typical soil management method in nursery fields. This method is commonly used to eliminate soilborne pathogens, insects, and nematodes [11,12]. Soil nematodes are not only decomposers, but they also increase soil porosity, which helps improve the soil environment $[13,14]$. However, some parasitic nematodes limit plant distribution in certain areas and have adverse effects on agricultural and forest crops. Nematodes have negative effects on plant growth $[15,16]$. The presence of parasitic nematodes, and their impact as pests on agriculture and forestry, have long been noted.

We conducted a soil fumigation study in an outdoor nursery that was infected with nematodes to investigate their effect on pine and larch seedlings. We examined changes in various soil properties after soil fumigation, and evaluated the effects thereof on the quantity and quality of $P$. densiflora and L. kaempferi seedlings after soil fumigation. We hypothesized that changes in soil properties due to soil fumigation, such as nematode density and nutrient status, would be favorable for seedling growth, improving seedling quantity and quality in the outdoor nursery.

\section{Materials and Methods}

\subsection{Site Description and Experimental Design}

This study was performed at Jeongseon National Nursery Station, Jeongseon-gun, Republic of Korea $\left(37^{\circ} 29^{\prime} 19^{\prime \prime} \mathrm{N}, 128^{\circ} 50^{\prime} 40^{\prime \prime} \mathrm{E}\right)$. The study area was $495 \mathrm{~m}$ above sea level, with a mean annual temperature of $12.4^{\circ} \mathrm{C}$ and mean annual precipitation of $940.4 \mathrm{~mm}$ in 2015 [17]. This nursery field had been affected by the production of seedlings in 2009 and 2011 by pests. In 2011, a study conducted by the National Institute of Forest Science of Korea showed that the damage was caused by take-all and root rot diseases. Five types of phytopathogenic nematodes, Pratylenchus sp., Tylenchus davainei, Psilenchus sp., Helicotylenchus dihystera and Dorylaimus sp., and Fusaruim genus, a pathogenic fungus, were detected in the nursery field soil and dead seedling [18].

To investigate the growth changes in pine and larch seedlings following soil fumigation, we established research plots in an outdoor nursery field. The treatment amount and application method were in accordance with the recommendations of the US Environmental Protection Agency [19]. Dazomet is a dimethyl compound (3,5-dimethyl-1,3,5-thiadiazinane-2-thione; chemical formula $\mathrm{C}_{5} \mathrm{H}_{10} \mathrm{~N}_{2} \mathrm{~S}_{2}$ ). In November 2014, the ground was sprayed with the soil fumigant Dazomet (granule form) at $30 \mathrm{~kg}$ per $0.1 \mathrm{ha}$. The soil was tilled twice to a depth of $15-25 \mathrm{~cm}$, before treatment of fumigant and directly before fumigation. The mixed soil was covered for 4 months using a black plastic sheeting after soil irrigation. In March 2015, the remaining gas was volatilized by tilling twice at 2-3 day intervals after removal of the cover. Untreated control plots were cultivated in the same manner. There were 14 control and 14 treatment plots $(2 \times 20 \mathrm{~m})$ for each species. To avoid interference by treatment, the distance between control and treatment plots was at least $10 \mathrm{~m}$ apart. In April 2015, pine and larch seeds were planted at a rate of $20.1 \mathrm{~g} \mathrm{~m}^{-2}$ or ca. 2800 and $5300 \mathrm{seeds} / \mathrm{m}^{2}$, respectively. Seedlings that died during the growth period were removed from the research plot.

\subsection{Soil Properties}

Soil samples were collected from depths of 0-10 $\mathrm{cm}$ at three randomly selected points in each plot using a core sampler $(\varnothing 36 \mathrm{~mm})$. The three samples were combined and mixed to generate a single sample for analysis. Before physical and chemical analyses, all soil samples were air-dried at room temperature and passed through a $2 \mathrm{~mm}$ soil sieve. Soil $\mathrm{pH}$ was determined after suspending the soil in distilled water at a ratio of $1: 5$ for $1 \mathrm{~h}$ and was measured using a $\mathrm{pH}$ meter (HM-30R; Toa Corp., Tokyo, Japan). Soil electrical conductivity ( $\mathrm{EC}_{1: 5}$ ) was analyzed using a conductivity meter (CM-30R; Toa), after suspending the soil in distilled water at a ratio of 1:5 for $1 \mathrm{~h}$ and filtering it using Whatman No. 42 filter paper. The concentrations of organic matter (OM) and total nitrogen (TN) were 
determined using an elemental analyzer (Vario MAX CN; Elementar Analysensysteme, Langenselbold, Germany). Available phosphorus $\left(\mathrm{AP} ; \mathrm{P}_{2} \mathrm{O}_{5}\right)$ was measured using an ultraviolet spectrophotometer (UV-2501PC; Shimadzu, Tokyo, Japan) via the Lancaster method, with an extracting solution based on the ammonium molybdate reaction. Cation exchange capacity (CEC) was determined by extraction with $1 \mathrm{~N}$ ammonium acetate at pH 7.0 and was measured with a pH meter (F-53; Horiba, Tokyo, Japan). The exchangeable potassium $\left(\mathrm{K}^{+}\right)$, sodium $\left(\mathrm{Na}^{+}\right)$, calcium $\left(\mathrm{Ca}^{2+}\right)$, and magnesium $\left(\mathrm{Mg}^{2+}\right)$ concentrations were determined by atomic absorption spectrophotometry (iCE 3000 Series; Thermo Fisher Scientific, Waltham, MA, USA) using $1 \mathrm{~N}$ ammonium acetate as the extracting solution.

Nematodes were extracted from a single core sample of soil $(\varnothing 36 \mathrm{~mm}$, depth $10 \mathrm{~cm})$ of each plot using a combination of sieving and decanting and the Baermann funnel technique [20]. The collected nematodes were killed and fixed in 4:1 formaldehyde:glycerin solution at $80{ }^{\circ} \mathrm{C}$. The nematode population density was determined under an inverted optical microscope (DE/DMI 3000B; Leica, Jena, Germany) and calculated per square meter $\left(\mathrm{m}^{2}\right)$.

\subsection{Seedling Growth}

We designated three $400 \mathrm{~cm}^{2}(20 \times 20 \mathrm{~cm})$ areas in the middle of each plot to examine the growth and quantity of seedlings per $\mathrm{m}^{2}$ (Figure 1). In September 2015, the pine and larch seedlings in these areas were harvested and the height, root collar diameter (RCD), dry weight (DW; needles, shoots, and root), and seedling quality index (SQI) were determined. SQI was calculated by Equation (1) [21].

$$
S Q I=D w /(H D \text { ratio }+S R \text { ratio })
$$

where $D w$ is the dry weight of the plant, the $H D$ ratio is the ratio of height $(\mathrm{cm})$ to $R C D(\mathrm{~mm})$, and the $S R$ ratio is the ratio of the dry weight of the shoots $(\mathrm{g})$ to that of the roots $(\mathrm{g})$.

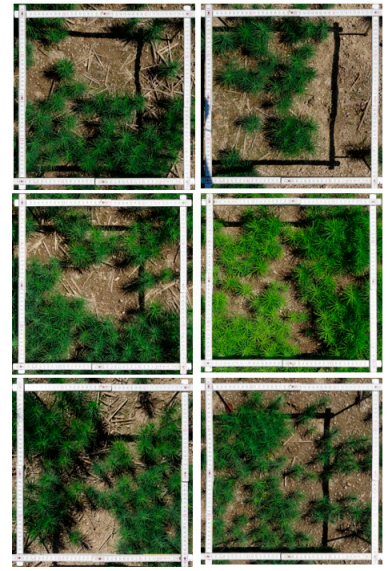

Control

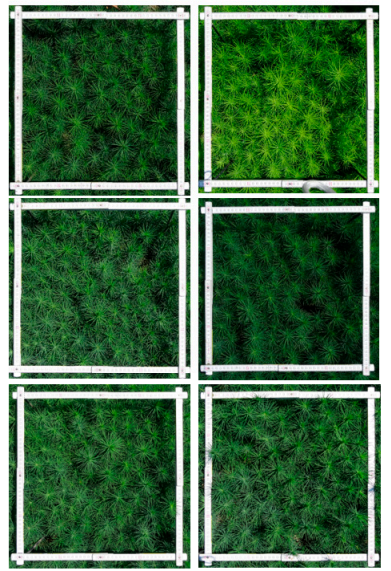

Treatment

\section{Pinus densiflora}

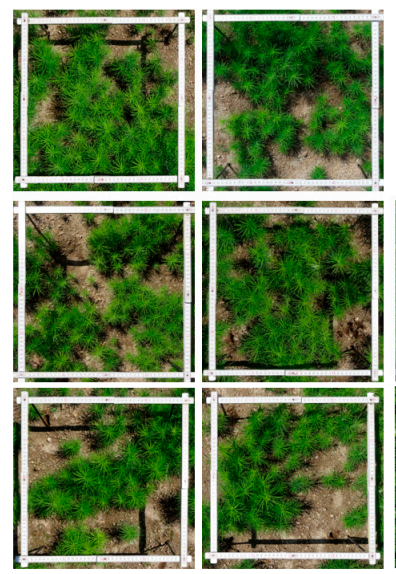

Control

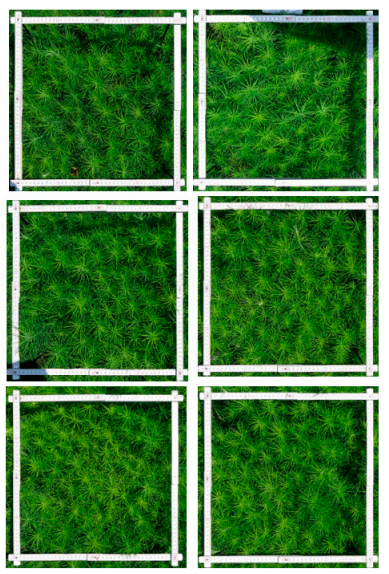

Treatment

\section{Larix kaempferi}

Figure 1. Photographs of pine and larch seedlings in control and soil fumigation treatment plots in the open-field nursery.

\subsection{Statistical Analysis}

All data were tested for normality and homogeneity of variance (Shapiro-Wilk and Levene's statistics). The Student's $t$-test was applied to compare soil properties, seedling survival rate, and seedling growth between the fumigant-treated and control soils using SPSS software (ver. 23.0; IBM Corp., Armonk, NY, USA). In addition, we employed nonmetric multidimensional scaling (NMDS) to examine the relationships between the soil properties and plant morphological properties, using the 
meta-multidimensional scaling and envfit functions in the Vegan library of R 2.15.3 (R Development Core Team, Vienna, Austria). A stepwise multiple regression analysis was performed using SPSS software to investigate the relationship between SQI and selected soil parameters based on the NMDS.

\section{Results}

\subsection{Changes in Soil Properties}

The soil fumigation treatment using Dazomet changed not only the nematode density but also the soil properties (Table 1). Our results show that soil fumigation greatly reduced the soil nematode density. The soil nematode density in the control plots was 2527.6 individuals per $\mathrm{m}^{2}$ of soil and that in the treatment plots was 105.3 individuals per $\mathrm{m}^{2}$ of soil. Soil nematodes were found in 20 of the 28 control plots, with a maximum of $1,4744.0$ individuals per $\mathrm{m}^{2}$ of soil, compared to 2 out of 28 treatment plots with a maximum of 1965.9 individuals per $\mathrm{m}^{2}$ of soil. Soil fumigation affected some of the chemical properties of the soil. After the fumigant treatment, the soil OM, CEC, and exchangeable $\mathrm{Mg}^{2+}$ content were significantly higher in the treatment soil, while the $\mathrm{EC}_{1: 5}$ was significantly lower.

Table 1. Soil nematode density and chemical properties after soil fumigation treatment in the open-field nursery.

\begin{tabular}{|c|c|c|c|c|c|c|c|c|c|c|c|}
\hline & $\begin{array}{l}\text { Nematode } \\
\text { Density }\end{array}$ & $\mathrm{pH}$ & $\begin{array}{l}\text { OM } \\
(\%)\end{array}$ & $\begin{array}{l}\text { TN } \\
(\%)\end{array}$ & $\begin{array}{c}\text { AP } \\
\left(\mathrm{mg} \mathrm{kg}^{-1}\right)\end{array}$ & $\begin{array}{c}\text { CEC } \\
\left(\mathrm{cmolc} \mathrm{kg}^{-1}\right)\end{array}$ & \multicolumn{4}{|c|}{ Exchangeable Cation (cmolc $\mathrm{kg}^{-1}$ ) } & $\begin{array}{c}E_{1: 5} \\
\left(\mathrm{dS} \mathrm{\textrm {m } ^ { - 1 }}\right)\end{array}$ \\
\hline Control & $\begin{array}{c}2527.6 \\
(3019.9)\end{array}$ & $\begin{array}{c}5.85 \\
(0.55)\end{array}$ & $\begin{array}{c}1.71 \\
(0.09)\end{array}$ & $\begin{array}{c}0.115 \\
(0.006)\end{array}$ & $\begin{array}{l}352.7 \\
(34.6)\end{array}$ & $\begin{array}{c}7.47 \\
(0.59)\end{array}$ & $\begin{array}{c}0.474 \\
(0.105)\end{array}$ & $\begin{array}{c}0.144 \\
(0.017)\end{array}$ & $\begin{array}{c}2.853 \\
(0.403)\end{array}$ & $\begin{array}{c}0.441 \\
(0.116)\end{array}$ & $\begin{array}{l}1.078 \\
(0.454)\end{array}$ \\
\hline Treatment & $\begin{array}{c}105.3 \\
(409.2)\end{array}$ & $\begin{array}{c}5.74 \\
(0.28)\end{array}$ & $\begin{array}{c}1.79 \\
(0.15)\end{array}$ & $\begin{array}{c}0.117 \\
(0.008)\end{array}$ & $\begin{array}{l}363.9 \\
(30.7)\end{array}$ & $\begin{array}{c}7.85 \\
(0.69)\end{array}$ & $\begin{array}{c}0.428 \\
(0.077)\end{array}$ & $\begin{array}{c}0.145 \\
(0.036)\end{array}$ & $\begin{array}{c}2.935 \\
(0.332)\end{array}$ & $\begin{array}{c}0.513 \\
(0.114)\end{array}$ & $\begin{array}{c}0.692 \\
(0.341)\end{array}$ \\
\hline
\end{tabular}

OM, organic matter; TN, total nitrogen; AP, available phosphorus; $\mathrm{CEC}$, cation exchange capacity; EC, electrical conductivity. The numbers in parentheses are the standard deviation.

\subsection{Effects of Soil Sterilization on Growth and Quantities of Seedlings}

The morphological properties of the two species grown in the control and fumigant treatment soil are summarized in Table 2. The pine and larch seedlings had different responses to sterilization; the mean quantity of pine seedlings increased significantly in the treated plots, while the mean quantity of larch tended to increase, but not significantly.

Table 2. Quantity and growth of pine and larch seedlings in the open-field nursery.

\begin{tabular}{|c|c|c|c|c|c|c|c|c|c|c|c|c|}
\hline & & $\begin{array}{l}\text { Seedling } \\
\text { Quantity }\end{array}$ & $\begin{array}{l}\text { Height } \\
\text { (cm) }\end{array}$ & $\begin{array}{l}\text { RCD } \\
(\mathrm{mm})\end{array}$ & $\begin{array}{l}\text { H/D } \\
\text { Ratio }\end{array}$ & $\begin{array}{c}\text { DW of } \\
\text { Needle (g) }\end{array}$ & $\begin{array}{c}\text { DW of } \\
\text { Stem (g) }\end{array}$ & $\begin{array}{c}\text { DW of } \\
\text { Shoot (g) }\end{array}$ & $\begin{array}{c}\text { DW of } \\
\text { Root (g) }\end{array}$ & $\begin{array}{c}\text { Total } \\
\text { DW (g) }\end{array}$ & $\begin{array}{c}\text { S/R } \\
\text { Ratio }\end{array}$ & SQI \\
\hline \multirow{3}{*}{$\begin{array}{c}\text { Pinus } \\
\text { densiflora } \\
\text { Siebold } \\
\text { \& Zucc. }\end{array}$} & Control & $\begin{array}{l}1869.6 \\
(480.6) \\
\end{array}$ & $\begin{array}{l}11.82 \\
(2.99)\end{array}$ & $\begin{array}{c}1.78 \\
(0.53)\end{array}$ & $\begin{array}{c}7.01 \\
(2.18)\end{array}$ & $\begin{array}{c}0.55 \\
(0.28)\end{array}$ & $\begin{array}{c}0.19 \\
(0.10)\end{array}$ & $\begin{array}{c}0.74 \\
(0.38)\end{array}$ & $\begin{array}{c}0.25 \\
(0.10)\end{array}$ & $\begin{array}{c}0.99 \\
(0.47)\end{array}$ & $\begin{array}{c}2.92 \\
(1.16)\end{array}$ & $\begin{array}{c}0.11 \\
(0.06)\end{array}$ \\
\hline & Treatment & $\begin{array}{l}2408.9 \\
(253.9)\end{array}$ & $\begin{array}{l}16.06 \\
(2.19)\end{array}$ & $\begin{array}{c}2.43 \\
(0.31)\end{array}$ & $\begin{array}{c}6.65 \\
(0.85)\end{array}$ & $\begin{array}{c}0.91 \\
(0.19)\end{array}$ & $\begin{array}{c}0.35 \\
(0.08)\end{array}$ & $\begin{array}{c}1.26 \\
(0.27)\end{array}$ & $\begin{array}{c}0.35 \\
(0.13)\end{array}$ & $\begin{array}{c}1.62 \\
(0.37)\end{array}$ & $\begin{array}{c}3.76 \\
(0.84)\end{array}$ & $\begin{array}{c}0.16 \\
(0.05)\end{array}$ \\
\hline & $p$-value & 0.001 & $<0.001$ & 0.001 & 0.576 & 0.001 & $<0.001$ & $<0.001$ & 0.025 & 0.001 & 0.036 & 0.016 \\
\hline \multirow{3}{*}{$\begin{array}{c}\text { Larix } \\
\text { kaempferi } \\
\text { (Lamb.) } \\
\text { Carrière }\end{array}$} & Control & $\begin{array}{l}2196.4 \\
(902.7)\end{array}$ & $\begin{array}{l}15.14 \\
(1.36)\end{array}$ & $\begin{array}{c}1.72 \\
(0.15)\end{array}$ & $\begin{array}{c}8.80 \\
(0.57)\end{array}$ & $\begin{array}{c}0.49 \\
(0.08)\end{array}$ & $\begin{array}{c}0.17 \\
(0.03)\end{array}$ & $\begin{array}{c}0.66 \\
(0.11)\end{array}$ & $\begin{array}{c}0.15 \\
(0.07)\end{array}$ & $\begin{array}{c}0.80 \\
(0.14)\end{array}$ & $\begin{array}{c}4.89 \\
(1.27)\end{array}$ & $\begin{array}{c}0.06 \\
(0.01)\end{array}$ \\
\hline & Treatment & $\begin{array}{l}2392.9 \\
(385.7)\end{array}$ & $\begin{array}{l}18.77 \\
(3.18)\end{array}$ & $\begin{array}{c}2.06 \\
(0.40)\end{array}$ & $\begin{array}{c}9.21 \\
(0.74)\end{array}$ & $\begin{array}{c}0.58 \\
(0.16)\end{array}$ & $\begin{array}{c}0.20 \\
(0.05)\end{array}$ & $\begin{array}{c}0.78 \\
(0.21)\end{array}$ & $\begin{array}{c}0.17 \\
(0.08)\end{array}$ & $\begin{array}{c}0.95 \\
(0.28)\end{array}$ & $\begin{array}{c}4.84 \\
(0.85)\end{array}$ & $\begin{array}{c}0.07 \\
(0.02)\end{array}$ \\
\hline & $p$-value & 0.464 & 0.001 & 0.011 & 0.112 & 0.081 & 0.033 & 0.060 & 0.417 & 0.089 & 0.910 & 0.234 \\
\hline
\end{tabular}

$\mathrm{RCD}$, root collar diameter; H/D, height/RCD; DW, dry weight; S/R, shoot/root; SQI, seedling quality index.

The numbers in parentheses are the standard deviation.

Figure 2 shows the regression curves between soil nematode density and the quantity of pine and larch seedlings in the plots containing nematodes. The quantities of pine and larch seedlings differed according to soil nematode density. The quantity of larch seedlings decreased markedly under high nematode density compared to the quantity of pine seedlings. 


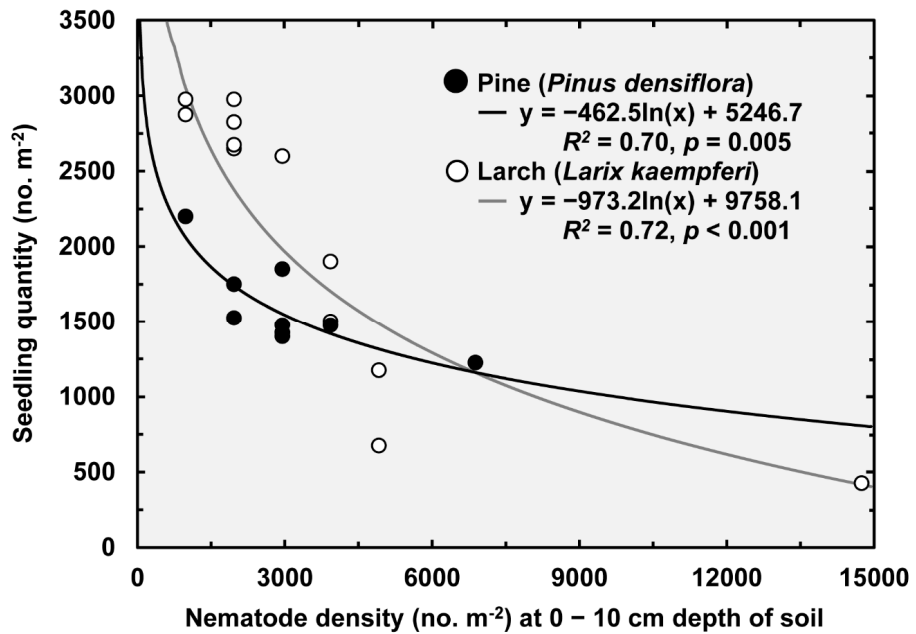

Figure 2. Relationship between soil nematode density and the quantity of pine and larch seedlings in the open-field nursery.

The sterilization treatment partially increased seedling growth. Seedling height and RCD increased significantly in both species in the sterilized soil. However, the increase in weight differed between the two species. The seedling DW of shoots and roots in the pine differed significantly between the treatment and control, but this was not the case for larch. Thus, the SQI improved significantly in the pine trees, but not in larch.

The factors that affected the growth of the two species also differed (Figure 3). The NMDS analysis of the relationships between pine growth and the properties of the soil revealed significant correlations with $\mathrm{AP}, \mathrm{Ca}^{2+}, \mathrm{Mg}^{2+}$, and $\mathrm{EC}_{1: 5}$. Larch growth was influenced by $\mathrm{EC}_{1: 5}$ and nematode density. Selected soil properties ( $\mathrm{AP}, \mathrm{Ca}^{2+}, \mathrm{Mg}^{2+}, \mathrm{EC}_{1: 5}$, and nematode density) included in the NMDS analysis were also considered in a stepwise multiple regression analysis of the SQI values of the pine and larch seedlings (Table 3). The results showed that only $\mathrm{EC}_{1: 5}$ was a significant factor in the SQI regression equation for pine and larch, explaining $33.4 \%$ and $28.2 \%$ of total variance, respectively.
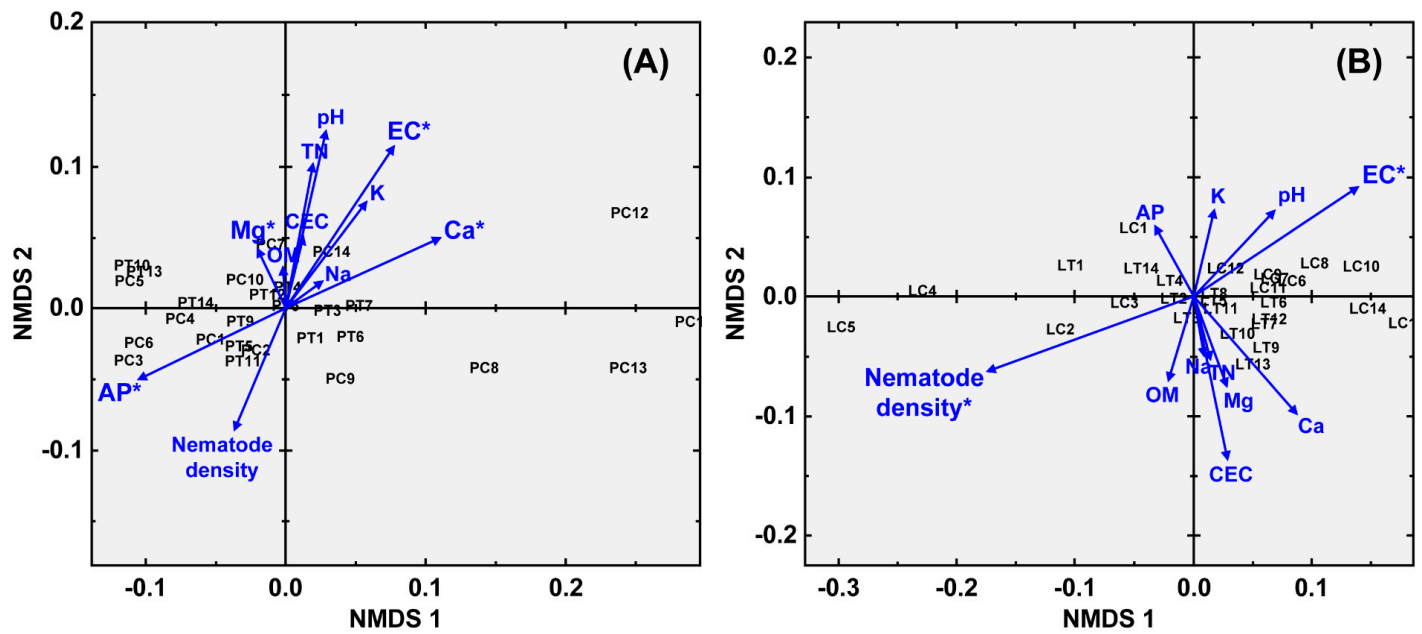

Figure 3. Nonmetric multidimensional scaling ordination between the morphological parameters of the (A) P. densiflora and (B) L. kaempferi and soil properties. Arrow direction indicates the correlation slope, and arrow length indicates the degree of influence of the various factors; ${ }^{*} p<0.05$. 
Table 3. Stepwise multiple regression analysis of seedling quality index (SQI) and selected soil parameters ( $\mathrm{AP}, \mathrm{Ca}^{2+}, \mathrm{Mg}^{2+}, \mathrm{EC}_{1: 5}$, and nematode density) from nonmetric multidimensional scaling (NMDS).

\begin{tabular}{ccccc}
\hline Species & Dependent Variable & Regression Equation & $\boldsymbol{R}^{\mathbf{2}}$ & $\boldsymbol{F}$-Value \\
\hline P. densiflora & Seedling quality index & $=0.191+\left(-0.066 \times \mathrm{EC}_{1: 5}\right)$ & 0.334 & $13.041(p=0.001)$ \\
L. kaempferi & Seedling quality index & $=0.091+\left(-0.030 \times \mathrm{EC}_{1: 5}\right)$ & 0.282 & $10.190(p=0.004)$ \\
\hline
\end{tabular}

\section{Discussion}

\subsection{Effects of Soil Sterilization on Soil Properties}

The objective of this study was to investigate the effect of soil fumigation on soil properties, and to determine the changes in growth of P. densiflora and L. kaempferi induced by soil fumigation. Dazomet fumigation remarkably reduced the soil nematode density. Soil sterilization is commonly used to eliminate pathogens, insects, and nematodes [11,12]. In our study, soil fumigation changed the soil chemical properties in different ways. As a result of the fumigation, OM, CEC, and $\mathrm{Mg}^{2+}$ increased, whereas $\mathrm{EC}_{1: 5}$ decreased.

We guessed that the increased soil OM in the treated soil was caused by removing the nematodes. Available $\mathrm{C}$ and $\mathrm{N}$ are not only regulated by microbes [22,23] but also influenced by the soil fauna [24]. Plant-feeding nematodes stimulate microbial growth by increasing the release of carbon-rich root exudates [25,26], thereby increasing soil OM decomposition via a mechanism known as the "priming effect" [27]. Bacteria-feeding nematodes increase the palatability of particulate matter through ingestion and excretion [28], although they do not assimilate soil OM [29,30]. The increase in microbial biomass and palatability of OM caused by the nematodes may have led to the rapid decomposition of the OM. Thus, removing the nematodes, which play an important role in OM decomposition, increased the soil OM by decreasing the decomposition rate. Soil fumigation also alters microbial biomass [31,32] and community structure [33-35], and these changes are known to affect soil enzyme activities [31]. The changes in soil microbial biomass and community structure affected the decomposition of the soil OM.

The increase in soil $\mathrm{Mg}^{2+}$ and CEC resulted from the inflow of nutrients originating from the decomposition of microbial debris. Various soil sterilization methods are known to affect soil nutrient status, such as the $\mathrm{NH}_{4}{ }^{+}$content [36], via decomposition of microbial debris [37]. In comparison, soil fumigation significantly reduced the $\mathrm{EC}_{1: 5}$. Decreases in electrical conductivity (EC) due to soil sterilization have been reported by several studies $[38,39]$. The exact reason why sterilization reduces the EC of soil is unknown, despite being mentioned by several studies. Gupta et al. [40] described how the instability of soil aggregates due to soil sterilization could change the electron exchange capacity. The heat generated during the sterilization process temporarily affects the EC [9]. We speculated that the reduction of EC was due to changes in the physical properties of the soil caused by the sterilization process $[9,40]$, while changes in the chemical properties were the result of changes in the biological properties, such as microbial community structure and enzymatic activities [31-35], and the release of microbial debris [36,37].

\subsection{Effects of Soil Sterilization on the Quantity and Quality of the Seedlings}

The quantity of pine seedlings was significantly altered by soil fumigation, whereas the quantity of larch seedlings was not; this was due to the response to low-density nematodes in the larch plot. When the density of soil nematodes was less than 3000 individuals per $\mathrm{m}^{2}$ of soil, the quantity of larch seedlings did not differ remarkably from the quantity when there were no nematodes. The regression analysis showed that the quantity of seedlings of the two species was negatively related to the density of soil nematodes (Figure 2). Although the relationship between the density of soil nematodes and the quantity of seedlings has not been studied extensively, a strong relationship with seedling mortality 
has been reported [41,42]. A previous study on a root-feeding caterpillar showed a reverse J-shaped relationship between the numbers of root-feeders and surviving seedlings [43]. Similarly, we observed a reverse J-shaped relationship between soil nematode density and the quantity of seedlings (Figure 2). It appeared that the quantity of seedlings decreased due to death rather than failed seed germination, where the seedlings were continuously damaged in the present study.

Soil fumigation also affected the growth and quantity of seedlings and, consequently, the seedling quality (Table 2). Although soil nematodes are known to affect plant growth [44,45], our results show that the factors affecting plant growth are more complex. The growth of the pine seedlings increased significantly according to all the morphological parameters, and the larch seedling partially improved the parameters compared to the seedling growth of the non-treatment soil. Factors affecting seedling growth differed between the two species (Figure 3). The growth of pine seedlings was affected by the soil chemical properties, such as $\mathrm{AP}, \mathrm{Ca}^{2+}, \mathrm{Mg}^{2+}$, and $\mathrm{EC}_{1: 5}$, while the growth of larch seedlings was affected by the $\mathrm{EC}_{1: 5}$ and nematode density. Although the larch $\mathrm{SQI}$ was not different, the $\mathrm{EC}_{1: 5}$ affected the growth of both species (Table 3). EC has been used as an indicator of soil salinity [46]. Salinity is an osmotic and ionic stress that poses a major threat to plant growth [47]. To evaluate the soil according to the United States Department of Agriculture (USDA) soil salinity classification [48], the $\mathrm{EC}_{1: 5}$ data in our study were converted to saturated soil paste EC (ECe) using the equation of Chi and Wang [49] $\left(\mathrm{ECe}=11.68 \times \mathrm{EC}_{1: 5}-5.77\right)$. The soil ECe in the non-fumigated soil was 6.82 under mild salinity (according to the USDA soil salinity classification), and that of the fumigated soil was 2.31 under low salinity. The growth of mildly sensitive plants can be affected by low salinity. Although the resistance of pine trees to salinity has not been determined precisely, it has been reported that tree vitality decreases as EC increases in Korean pine forests [50]. Thus, pines are saline-sensitive such that the decrease in EC due to soil fumigation improved the quality of the pine seedlings in our study. Although regression analysis showed that the larch seedling quality was affected by $\mathrm{EC}_{1: 5}$, there was no significant difference according to the fumigation treatment. The decrease in soil salinity did not greatly improve the growth of larch seedlings. Larch is known to be tolerant to soil salinity [51]. The relationship between the SQI and $\mathrm{EC}_{1: 5}$ of larch showed a lower slope than that between the SQI and $\mathrm{EC}_{1: 5}$ of pine (Table 3), indicating that larch was less affected by salinity. These results suggest that changes in seedling growth and quality due to soil fumigation were affected not only by soil nematode density, but also by changes in the chemical properties of the soil caused by fumigation.

Our results showed that soil fumigation to control soil nematodes greatly improved the production of healthy seedlings, particularly pine trees. Reducing the number of nematodes by soil fumigation increased the quantity of the seedlings produced, and the change in soil chemical properties improved seedling quality as a secondary effect of fumigation. Soil fumigation proved a very effective soil management treatment to increase the quantity of pine seedlings by controlling the nematode density, and to improve their quality by reducing the EC. Although the quality of larch seedlings did not improve, soil fumigation increased the quantity of seedlings by controlling the soil nematode density. These results suggest that controlling the density of soil nematodes is very important for seedling production in field nurseries. Knowledge of the response of plant species to management could improve agricultural and forestry economics. The accumulation of such data will contribute to increase productivity in crop and nursery fields.

\section{Conclusions}

We conclude that soil fumigation with Dazomet affected various soil properties; it not only reduced the number of soil nematodes but also changed the OM, CEC, $\mathrm{Mg}^{2+}$, and EC of the soil. Notable changes included the reduction in nematode density and EC. Decreasing the number of soil nematodes resulted in an increased number of healthy seedlings. The quantities of pine and larch seedlings were highly correlated with the density of the soil nematode, indicating that soil fumigation improves seedling production by removing nematodes. The soil properties changed due to the secondary effect of soil fumigation on the growth of both species, but the factors affecting their growth were different. 
The growth of pine seedlings was affected by soil chemical properties, such as $\mathrm{AP}, \mathrm{Ca}^{2+}, \mathrm{Mg}^{2+}$, and EC, while the growth of the larch seedlings was affected by EC and nematode density. The two tree species showed different seedling quality results. Although the SQI of both species was related to the EC, only the quality of the pine seedlings improved. As pine is sensitive to soil salinity, changes in the EC had a greater influence on the growth of pine seedlings, while larch was tolerant to salinity and was less affected. This means that soil management by fumigation to control nematodes is a very effective method for improving the production of seedlings. The benefits of soil fumigation for forest tree seedling production could be extended beyond the nursery to the millions of hectares of forests that depend on healthy seedlings for their establishment.

Author Contributions: Conceptualization: Y.S.K.; methodology: J.C. and Y.S.K.; field survey and data collection: I.G.C., J.C., and Y.S.K.; formal analysis: S.C., J.K., I.G.C., H.H., and Y.S.K.; data curation: S.C. and Y.S.K.; writing-original draft preparation: S.C. and J.K.; writing-review and editing: S.C. and Y.S.K.; visualization: S.C.; supervision: Y.S.K.; project administration: N.K. and Y.S.K.; funding acquisition: Y.S.K.

Funding: This research received no external funding.

Acknowledgments: None.

Conflicts of Interest: The authors declare no conflict of interest.

\section{References}

1. Korea Forest Service. Available online: http://www.forest.go.kr/newkfsweb/cop/bbs/selectBoardArticle. do;jsessionid=nudQpkpKwO3uaYzd2ACXHlvU5azH1afY9Lu5Gtz7SLs8DBW4yAODrT91Ub6mOmQJ. frswas01_servlet_engine1?nttId=3117489\&bbsId=BBSMSTR_1069\&pageIndex=1\&pageUnit=10\& searchtitle=title\&searchcont=\&searchkey=\&searchwriter=\&searchdept=dept\&searchWrd=\%ec $\% 96 \% 91 \%$ eb\%ac\%98\%ec\%9e\%a5\&ctgryLrcls=\&ctgryMdcls=\&ctgrySmcls=\&ntcStartDt=\&ntcEndDt=\&orgId=kfs\& mn=KFS_02_09_01 (accessed on 1 July 2019).

2. Mattsson, A. Predicting field performance using seedling quality assessment. New For. 1997, 13, $227-252$. [CrossRef]

3. Brand, D.G.; Margolis, H.A. An ecophysiological basis for understanding plantation establishment. Can. J. For. Res. 1990, 20, 375-390.

4. Ritchie, G.A.; Shula, R.G. Seasonal changes of tissue-water relations in shoots and root systems of douglas-fir seedlings. For. Sci. 1984, 30, 538-548. [CrossRef]

5. Duryea, M.L. Proceedings, Evaluating Seedling Quality: Principles, Procedures, and Predictive Abilities of Major Tests; Oregon State University: Corvallis, OR, USA, 1985.

6. Burdett, A.N. Physiological processes in plantation establishment and the development of specifications for forest planting stock. Can. J. For. Res. 1990, 20, 415-427. [CrossRef]

7. Wightman, K.E.; Shear, T.; Goldfarb, B.; Haggar, J. Nursery and field establishment techniques to improve seedling growth of three Costa Rican hardwoods. New For. 2001, 22, 75-96. [CrossRef]

8. Tanaka, S.; Kobayashi, T.; Iwasaki, K.; Yamane, S.; Maeda, K.; Sakurai, K. Properties and metabolic diversity of microbial communities in soils treated with steam sterilization compared with methyl bromide and chloropicrin fumigations. Soil Sci. Plant Nutr. 2003, 49, 603-610. [CrossRef]

9. Takayama, M.; Ikegami, T.; Ogata, K.; Stryczewska, H.D.; Gyoutoku, Y.; Sakai, T.; Ebihara, K. Development of Agricultural Soil Sterilization Using Ozone Generated by High Frequency Dielectric Barrier Discharge. J. Adv. Oxid. Technol. 2006, 9, 170-173.

10. Buchan, D.; Moeskops, B.; Ameloot, N.; de Neve, S.; Sleutel, S. Selective sterilisation of undisturbed soil cores by gamma irradiation: Effects on free-living nematodes, microbial community and nitrogen dynamics. Soil Biol. Biochem. 2012, 47, 10-13. [CrossRef]

11. Friberg, H.; Lagerlöf, J.; Rämert, B. Influence of soil fauna on fungal plant pathogens in agricultural and horticultural systems. Biocontrol Sci. Technol. 2005, 15, 641-658. [CrossRef]

12. Hasna, M.K.; Lagerlöf, J.; Rämert, B. Effects of fungivorous nematodes on corky root disease of tomato grown in compost-amended soil. Acta Agric. Scand. B-Soil Plant Sci. 2008, 58, 145-153. [CrossRef] 
13. Blanc, C.; Sy, M.; Djigal, D.; Brauman, A.; Normand, P.; Villenave, C. Nutrition on bacteria by bacterial-feeding nematodes and consequences on the structure of soil bacterial community. Eur. J. Soil Biol. 2006, 42, S70-S78. [CrossRef]

14. USDA. Available online: http://www.nrcs.usda.gov/wps/portal/nrcs/detailfull/soils/health/biology/?cid= .nrcs142p2_053866/ (accessed on 30 September 2017).

15. Barker, K.R.; Olthof, T.H.A. Relationships between Nematode Population Densities and Crop Responses. Annu. Rev. Phytopathol. 1976, 14, 327-353. [CrossRef]

16. Bridge, J.; Starr, J.L. Plant Nematodes of Agricultural Importance: A Colour Handbook; CRC Press: Boca Raton, FL, USA, 2007.

17. Korea Meteorological Administration. Available online: http://www.weather.go.kr/weather/climate/past_ .table.jsp (accessed on 12 May 2018).

18. Lee, S.K. Results of the Survey on the Pest of Larch Seedling in Nursery Filed; National Institute of Forest Science: Seoul, Korea, 2011; unpublished work.

19. U.S. Environmental Protection Agency. Reregistration Eligibility Decision (RED) for Dazomet. EPA 738-R-08-007; U.S. Environmental Protection Agency: Washington, DC, USA, 2008.

20. Barker, K.R. Nematode extraction and bioassays. In An Advanced Teatise on Meloidogyne; Barker, K.R., Carter, C.C., Sasser, J.N., Eds.; North Carolina State University Graphics: Raleigh, NC, USA, 1985; Volume 2, pp. 19-35.

21. Dickson, A.; Leaf, A.L.; Hosner, J.F. Seedling quality-Soil fertility relationships of white spruce, and red and white pine in nurseries. For. Chron. 1960, 36, 237-241. [CrossRef]

22. Schimel, J.P.; Bennett, J. Nitrogen mineralization: challenges of a changing paradigm. Ecology 2004, 85, 591-602. [CrossRef]

23. Craine, J.M.; Morrow, C.; Fierer, N. Microbial nitrogen limitation increases decomposition. Ecology 2007, 88, 2105-2113. [CrossRef] [PubMed]

24. Osler, G.H.R.; Sommerkorn, M. Toward a complete soil C and N cycle: Incorporating the soil fauna. Ecology 2007, 88, 1611-1621. [CrossRef] [PubMed]

25. Denton, C.S.; Bardgett, R.D.; Cook, R.; Hobbs, P.J. Low amounts of root herbivory positively influence the rhizosphere microbial community in a temperate grassland soil. Soil Biol. Biochem. 1998, 31, 155-165. [CrossRef]

26. Saggar, S.; Mercer, C.; Hedley, C.; Yeates, G. Increase in 14C-carbon translocation to the soil microbial biomass when five species of plant-parasitic nematodes infect roots of white clover. Nematology 1999, 1, 295-300. [CrossRef]

27. Gebremikael, M.T.; Steel, H.; Buchan, D.; Bert, W.; de Neve, S. Nematodes enhance plant growth and nutrient uptake under C and N-rich conditions. Sci. Rep. 2016, 6, 32862. [CrossRef]

28. Freckman, D.W. Bacterivorous nematodes and organic-matter decomposition. Agric. Ecosyst. Environ. 1988, 24, 195-217. [CrossRef]

29. Yeates, G.W. Feeding types and feeding groups in plant and soil nematodes. Pedobiologia 1971, 11, $173-179$.

30. Twinn, D.C. Nematodes. In Biology of Plant Litter Decomposition; Dickinson, C.H., Pugh, G.J.F., Eds.; Academic Press: London, UK, 1974; Volume 2, pp. 421-465.

31. Klose, S.; Ajwa, H.A. Enzyme activities in agricultural soils fumigated with methyl bromide alternatives. Soil Biol. Biochem. 2004, 36, 1625-1635. [CrossRef]

32. Eo, J.; Park, K.-C. Effects of dazomet on soil organisms and recolonisation of fumigated soil. Pedobiologia 2014, 57, 147-154. [CrossRef]

33. Klose, S.; Acosta-Martinez, V.; Ajwa, H.A. Microbial community composition and enzyme activities in a sandy loam soil after fumigation with methyl bromide or alternative biocides. Soil Biol. Biochem. 2006, 38, 1243-1254. [CrossRef]

34. Scopa, A.; Dumontet, S. Soil Solarization: Effects on Soil Microbiological Parameters. J. Plant Nutr. 2007, 30, 537-547. [CrossRef]

35. Bonanomi, G.; Chiurazzi, M.; Caporaso, S.; del Sorbo, G.; Moschetti, G.; Felice, S. Soil solarization with biodegradable materials and its impact on soil microbial communities. Soil Biol. Biochem. 2008, 40, 1989-1998. [CrossRef] 
36. Gelsomino, A.; Badalucco, L.; Landi, L.; Cacco, G. Soil Carbon, Nitrogen and Phosphorus Dynamics as Affected by Solarization Alone or Combined with Organic Amendment. Plant Soil 2006, 279, 307-325. [CrossRef]

37. Yamamoto, T.; Ultra, V.U.; Tanaka, S.; Sakurai, K.; Iwasaki, K. Effects of methyl bromide fumigation, chloropicrin fumigation and steam sterilization on soil nitrogen dynamics and microbial properties in a pot culture experiment. Soil Sci. Plant Nutr. 2008, 54, 886-894. [CrossRef]

38. Horton, D.L.; Pfeiffer, D.G.; Hendrix, F.F. Research and education in the southern region. In Sustainable Agriculture Research and Education in the Field. A Proceedings; Rice, B.J., Ed.; National Academy Press: Washington, DC, USA, 1991; pp. 221-222.

39. Stapleton, J.J. Thermal inactivation of crop pests and pathogens and other sol changes caused by solarization. In International Conference of Soil Solarization, Ammam. Proceedings; deVay, J.E., Stapleton, J.J., Elmore, C.L., Eds.; FAO Plant Protection and Production Paper: Rome, Italy, 1991.

40. Gupta, S.; Singh, R.P.; Rautela, P. Effect of soil solarization on physio chemical properties of soil under protected cultivation. Int. J. Chem. Stud. 2017, 5, 2039-2042.

41. Futai, K. Population Dynamics of Bursaphelenchus lignicolus (Nematoda: Aphelenchoididae) and B. mucronatus in Pine Seedlings. Appl. Èntomol. Zoöl. 1980, 15, 458-464. [CrossRef]

42. Mamiya, Y.; Shoji, T. Pathogenicity of the pinewood nematode, Bursaphelenchus xylophilus, to Japanese larch, Larix kaempferi, seedlings. J. Nematol. 2009, 41, 157-162. [PubMed]

43. Strong, D.R.; Whipple, A.V.; Child, A.L.; Dennis, B. Model seletion for a subterranean trophic cascade: Root-feeding caterpillars and entomopathogenic nematodes. Ecology 1999, 80, 2750-2761. [CrossRef]

44. Ruehle, J.L. Influence of Plant-Parasitic Nematodes on Longleaf Pine Seedlings. J. Nematol. 1973, 5, 7-9. [PubMed]

45. Welsh, C.E.; Guertal, E.A.; Wood, C.W. Effects of soil fumigation and N source on soil inorganic N and tomato growth. Nutr. Cycl. Agroecosys 1998, 52, 37-44. [CrossRef]

46. Rhoades, J.; Chanduvi, F. Soil Salinity Assessment: Methods and Interpretation of Electrical Conductivity Measurements; FAO: Rome, Italy, 1999.

47. Colmer, T.D.; Flowers, T.J. Flooding tolerance in halophytes. New Phytol. 2008, 179, 964-974. [CrossRef] [PubMed]

48. Shirokova, Y.; Forkutsa, I.; Sharafutdinova, N. Use of Electrical Conductivity Instead of Soluble Salts for Soil Salinity Monitoring in Central Asia. Irrig. Drain. Syst. 2000, 14, 199-206. [CrossRef]

49. Chi, C.-M.; Wang, Z.-C. Characterizing salt-affected soils of Songnen Plain using saturated paste and 1:5 soil-to-water extraction methods. Arid Land Res. Manag. 2010, 24, 1-11. [CrossRef]

50. Park, S.-G.; Hong, S.-H.; Oh, C.-J. A Study on Correlation Between the Growth of Korean Red Pine and Location Environment in Temple Forests in Jeollanam-do, Korea. Korean J. Environ. Ecol. 2017, 31, 409-419. [CrossRef]

51. The Morton Arboretum. Available online: https://www.mortonarb.org/trees-plants/tree-plant-descriptions/ japanese-larch (accessed on 1 July 2019).

(C) 2019 by the authors. Licensee MDPI, Basel, Switzerland. This article is an open access article distributed under the terms and conditions of the Creative Commons Attribution (CC BY) license (http://creativecommons.org/licenses/by/4.0/). 